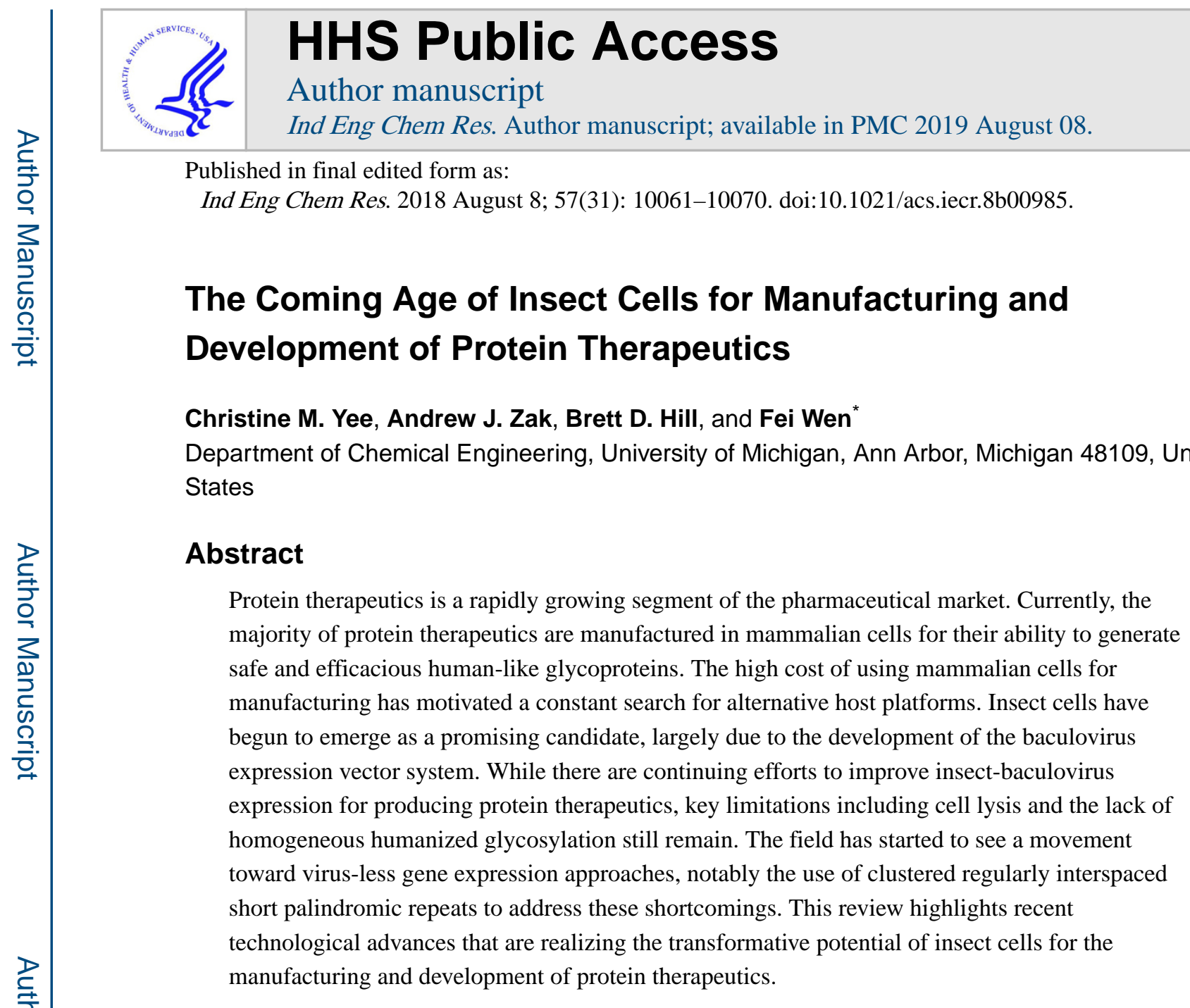

\title{
Abstract
}

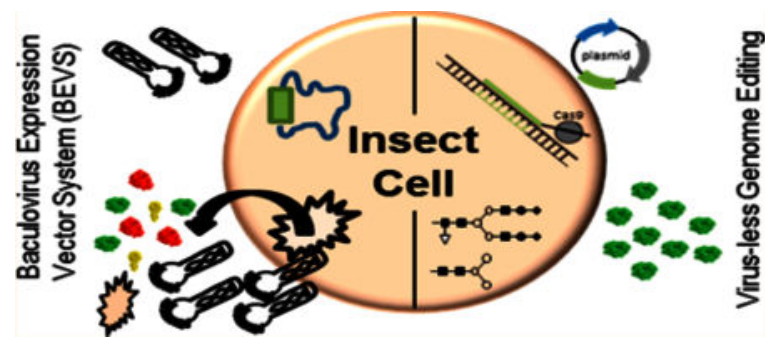

\section{PROMISES AND CHALLENGES}

Protein therapeutics represents a rapidly growing segment of the pharmaceutical industry that is estimated to reach a market value of $\$ 316$ billion by $2025 .^{1,2}$ Protein therapeutics include a variety of products ranging from subunits of a single protein to complex virus-like particles (VLPs) consisting of multiple proteins. ${ }^{3-6}$ Unlike small-molecule drugs, which had

*Corresponding Phone: 734-764-8723. feiwenum@umich.edu. Author Contributions

The manuscript was written through contributions of all authors. All authors have given approval to the final version of the manuscript. The authors declare no competing financial interest. 
dominated the market prior to several biotechnological advances in the late 1900s ${ }^{7}$ (Figure 1), protein therapeutics are necessarily manufactured using living cells because of common protein properties such as large size, complex structure, and, for some, post-translational modifications. ${ }^{2,3,7}$ By the end of 2014, $\sim 60 \%$ of the U.S. Food and Drug Administration (FDA) and European Medicines Agency (EMA) approved recombinant protein therapeutics were produced in mammalian cell lines, mainly due to their natural ability to produce human-like glycoproteins. ${ }^{8,9}$ This ability is important when certain glycan structures affect the efficacy of the protein therapeutic or when foreign glycan structures induce undesired immune responses. ${ }^{10-12}$ Despite this advantage, mammalian cell lines are associated with high costs of maintenance and scale up. ${ }^{13}$ Therefore, more economical and scalable production hosts, such as yeast or bacteria, are used for manufacturing and account for the remaining $\sim 40 \%$ of approved protein therapeutics in the market. In spite of much progress in genetic engineering, lower microbes have limited ability to express and fold proteins with co- and post-translational modifications, including glycosylation. ${ }^{14-16}$ Because nonhuman glycosylation poses concerns regarding safety and efficacy of protein therapeutics, there is a constant search in the field for an ideal production host with a fine balance between its glycosylation capabilities and cost effectiveness.

Having long been used as a model eukaryote in physiology and pathology research, ${ }^{17,18}$ insect cells have begun to show promise as a potential candidate for manufacturing and developing protein therapeutics. The most widely used insect cell lines include S2 derived from Drosophila melanogaster, Sf9 from Spodoptera frugiperda, and High Five from Trichoplusia ni. These and other insect cell lines offer several manufacturing advantages over mammalian cells, including no $\mathrm{CO}_{2}$ requirement, lower energy requirement due to incubation at lower temperatures, and reduced biosafety requirements (BSL1). ${ }^{19-21} \mathrm{In}$ addition, as a higher eukaryote, insect cells naturally produce more complex glycan structures than yeast or bacteria. Unfortunately, their potential as a manufacturing host to produce protein therapeutics has been unrealized because the initial genetic tools developed for engineering insect cells were time consuming and had low throughput. For example, protein expression in $\mathrm{S} 2$ cells has been primarily accomplished by transforming a plasmid encoding the gene of interest and an antibiotic selection marker, followed by selection and expansion of the high-expressing clones to obtain a stable cell line needed for large-scale protein production. This process, generally termed random integration, usually takes $2-3$ months.

The development of the baculovirus expression vector system (BEVS) in 1983 dramatically improved the potential and applicability of insect cells for producing protein therapeutics ${ }^{22,23}$ (Figure 1). BEVS gained popularity by enabling high yields of recombinant protein expression using the strong late viral polyhedrin (polh) promoter. ${ }^{24-26}$ Compared to early promoters (e.g., ie1 and ETL) used in BEVS, the polh promoter-induced expression is consistently higher. ${ }^{27-29}$ Moreover, BEVS has reduced the production timeline by more than half, bypassing the need for creating stable cell lines. Since the commercialization of BEVSbased expression kits in the mid-1990s, BEVS has quickly established itself as a staple genetic tool for recombinant protein production in insect cells and has greatly accelerated their use for protein therapeutics development. ${ }^{30,31}$ The combined advantages of the baculovirus-insect cell system led to the approval of five veterinary vaccines between 2000- 
$2009,31,32$ followed by another four vaccines for human use in the past decade (Figure 1). Insect cell-derived protein therapeutics now constitute $\sim 1 \%$ of all FDA/EMA approved protein therapeutics for human use, including a VLP-based vaccine against cervical cancer (Cervarix, the human papillomavirus L1 protein is purified from High Five), ${ }^{33}$ a cellular immunotherapy against prostate cancer (Provenge, the prostatic acid phosphatase is purified from Sf21), ${ }^{34,35}$ a gene therapy against familial lipoprotein lipase deficiency (Glybera, adenovirus vector is produced in Sf9), ${ }^{36}$ and a subunit vaccine for influenza (Flublok, hemagglutinin protein is produced in Sf9). ${ }^{37}$

To realize the full potential of insect cells in the manufacturing and development of protein therapeutics, two intrinsic limitations of the baculovirus-insect cell system must be addressed. First, because BEVS relies on the infection of cells with actively replicating viruses, large amounts of baculovirus progeny contaminate the culture along with cellular proteins and debris from lysed cells. These contaminants necessitate costly purification steps to meet pharmaceutical-grade purity for clinical applications. ${ }^{38-40}$ Second, insect cellderived recombinant proteins contain altered and less-complex glycan structures compared to the human and mammalian equivalents, ${ }^{30,41,42}$ which may impair their efficacy and safety. Therefore, engineering humanized glycosylation pathways in insect cells is essential.

While various strategies have been devised to address these limitations, targeted genome editing has the potential to bypass some of these challenges altogether. In this review, we highlight the most recent technological advances, with an emphasis on how they can effectively overcome these challenges and accelerate the adoption of insect cells for manufacturing and development of protein therapeutics.

\section{CONTINUING EFFORTS TO IMPROVE THE BACULOVIRUS EXPRESSION VECTOR SYSTEM (BEVS)}

For more than 30 years, BEVS has been the workhorse for recombinant protein expression and virus-like particle (VLP) production in Sf9 and High Five cells, which are more permissive to baculovirus infection and replication compared to other insect cell lines. 26,43,44 The most commonly used system, Bac-to-Bac, begins by cloning a gene of interest (GOI) into a transfer plasmid under a strong viral promoter such as the polh or p10 promoters. ${ }^{24,26}$ After transforming the plasmid into a specialized strain of E. coli containing a shuttle vector (bacmid), ${ }^{45}$ the GOI is transposed into the baculovirus genome (Figure 2, Step A). The modified recombinant baculovirus genome is then transfected into insect cells resulting in viral replication to produce viral progeny (Figure 2, Step B). This initial lowtiter baculovirus stock harvested from the transfection step is then amplified to create the high-titer stock (Figure 2, Step C). Finally, protein expression is carried out on a larger scale by infecting insect cells with the high-titer baculovirus stock to achieve a high yield of the desired protein (Figure 2, Step D). Since the polh and p10 promoters are late-stage promoters, production of the target protein occurs late in the viral replication cycle (48-72 $\mathrm{h}$ postinfection) along with the expression of late viral apoptotic proteins leading to cell lysis (72-96 $\mathrm{h}$ postinfection). ${ }^{46,47}$ 
The short time window between recombinant protein expression and cell lysis presents several challenges uniquely associated with BEVS. First, cell lysis releases large amounts of cellular debris, protein, and intact baculovirus particles, complicating downstream product purification of the target protein. ${ }^{40,46}$ Furthermore, degradation of the target protein by released proteases may occur before protein purification is completed. ${ }^{48}$ Additionally, there is insufficient time for the target protein to undergo complete processing of post-translational modifications. ${ }^{48}$ As a result, the target protein may exhibit a range of glycan structures at the time of harvest, affecting the efficacy and/or safety of the product. With the goal to simplify product purification or to promote homogeneous humanized glycosylation, several strategies have been developed to reduce cell lysis associated with BEVS (Figure 2).

\subsection{Reducing Contaminants during Manufacturing.}

Typically, the target protein is purified by a combination of membrane filtration and chromatography techniques where significant protein losses occur. ${ }^{40}$ To increase the overall yield and reduce manufacturing costs, several strategies have focused on delaying cell lysis (Figure 2, Step D). One strategy is to delete genes in the baculovirus genome that encode proteins involved in cell lysis. It has been shown that the deletion of both chitinase and vcathepsin resulted in significantly less degradation and overall improvement in the yield of the sporozoite surface protein $\mathrm{p} 67$, a potential subunit vaccine candidate. ${ }^{49}$ Another strategy to delay cell lysis is to increase the expression of antiapoptotic proteins. Viral ankyrins (vankyrins) derived from an insect polydnavirus have been identified as I- $x$ B homologues that act on the NF- $\kappa$ B signaling pathway to block cellular apoptosis. By expressing and testing seven different vankyrins using BEVS, P-vank-1 and $\mathrm{I}^{2}$-vank-3 were shown to maintain cell viability to $>90 \%$ about 96 h postinfection in both Sf 9 and High Five cells. ${ }^{50}$ In another experiment, expressing the ie 1 transcriptional enhancer transactivated the promoter of $\mathrm{p} 35$, a suppressor of apoptosis. This not only led to a 4-fold increase in green fluorescent protein (GFP) production, but also extended cell viability to $>50 \%$ about $120 \mathrm{~h}$ postinfection. ${ }^{51}$

When producing VLP in insect cells, the budded and occluded baculoviruses in the cell culture supernatant are often present in large excess (>10:1) compared to the VLP. ${ }^{52}$ In addition, many VLPs and baculoviruses are similar in size and density, making their separation a highly challenging task. To prevent the extensive contamination of baculovirus and facilitate easier VLP purification, engineering strategies have focused on deleting baculovirus genes involved in its replication cycle. VP80 is a baculovirus structural protein required for both virion packaging and release from the nucleus. ${ }^{53}$ The use of VP80-null baculovirus enabled expression of recombinant enhanced green fluorescent protein (EGFP) without producing any progeny virus. ${ }^{54}$ In a similar manner, the deletion of GP64, a major baculoviral protein involved in cell entry, ${ }^{55-57}$ has been shown to decrease the amount of baculovirus in the supernatant when producing HIV-1 Gag VLP. ${ }^{58}$

While deleting genes related to the viral replication cycle promotes cleaner expression, this strategy impairs amplification of the high-titer viral stocks required for efficient protein expression (Figure 2, Step C). To address this problem, a separate cell line can be engineered to functionally complement the deleted gene in the mutant baculovirus during viral 
amplification. This strategy has been applied for the VP80-null baculovirus, but the resulting transcomplementation system was still $\sim 25$ times less effective in viral amplification than the wild-type baculovirus. ${ }^{54}$ The vesicular stomatitis virus G (VSV-G) protein, a functional analogue to GP64, has also been used to transcomplement the defect of the GP64-null baculovirus, resulting in 10- to 100 -fold lower baculovirus titers. ${ }^{59}$ Further improvement of this transcomplementation strategy may be needed to restore the viral amplification to the wild-type level.

\subsection{Engineering Humanized Glycosylation Pathways Using BEVS.}

Asparagine-linked glycan (N-glycan) structures on insect cell-derived proteins have been well characterized and show significant differences from those produced in mammalian cells. ${ }^{41,60-62}$ Glycan structures from both types of cells share an internal paucimannose structure (Table $1 ;$ lines 1,2 ). In mammalian cells, $\mathrm{N}$-acetylglucosaminyltransferase adds a GlcNAc (N-acetylglucosamine) residue to both mannose branches, and additional glycotransferases elongate the branch with galactose followed by sialic acid residues (Table 1; line 1). However, insect cells also express $\mathrm{N}$-acetylglucosaminidase that removes GlcNAc residues and outcompetes the activity of $\mathrm{N}$-acetylglucosaminyltransferase, preventing further elongation of both branches. Thus, while human proteins have biantennary (two branches) and terminally sialylated glycan structures, the majority $(>90 \%)$ of insect proteins are terminally mannosylated (Table 1 ; line 2). ${ }^{63,64}$

These differences between insect and human glycosylation have been shown to directly affect the efficacy of protein therapeutics. Compared to the mammalian equivalents, human thyroid-stimulating hormone and human interferon- $\gamma$ derived from insect cells were cleared more rapidly from the bloodstream in mouse and rabbit models, respectively. ${ }^{65,66}$ The reduced bioavailability of both proteins can be attributed to mannose receptor-mediated endocytosis by hepatic endothelial cells and macrophages (Kupffer cells). ${ }^{67-70}$ Studies have also suggested that the lower bioavailability of insect cell-derived proteins leads to reduced immune stimulation, as weaker humoral responses (i.e., lower neutralizing antibody titers and $\mathrm{IgG1}$ :IgG2a ratio) were observed in animal models vaccinated with influenza HA protein produced from $\mathrm{Sf} 9$ and $\mathrm{S} 2$ cells compared to HA produced from mammalian cells. This reduced humoral immune response resulted in less protection against H5N1 viral challenge. ${ }^{71,72}$ Insect cell N-glycan structures can also directly impair immune functions independent of reduced bioavailability. Immunosuppression of dendritic cell activity through mannose binding to the dendritic cell-specific intercellular adhesion molecule-3-grabbing nonintegrin (DC-SIGN) receptor was observed in vitro for both mannosylated HA and HIV gp120 proteins. ${ }^{72-74}$

While the lack of mammalian glycan structures reduces efficacy, some insect-specific Nglycan structures found in certain insect cell lines pose safety concerns. Both insect and human glycoproteins share $a-1,6$-core fucosylation on the proximal GlcNAc group. However, High-Five and related cell lines derived from Trichoplusia ni produce glycoproteins with an additional $a-1,3$-core fucosylation on the same group (Table 1; line 14). ${ }^{75,76}$ This is accomplished by fucosyl-transferase 8 (FUT8), which is absent in mammalian cells. ${ }^{9,12}$ The $a-1,3$-core fucose residue has been identified as an IgE epitope 
for individuals allergic to honeybee venom and can cause severe reactions. ${ }^{75}$ Reduced efficacy and safety concerns associated with these insect glycan structures have thus motivated the engineering of insect cells to produce protein therapeutics with humanized glycosylation.

Expression of mammalian glycotransferases using BEVS has been the primary strategy to achieve humanized glycosylation in insect cells. Early efforts utilized coinfection of one baculovirus encoding mammalian glycotransferases and a second encoding the target protein. This was first accomplished in Sf9 cells infected with a baculovirus encoding the human $\mathrm{N}$-acetylglucosaminyltransferase I (GlcNAc-TI) under the late p10 promoter, which added a terminal GlcNAc residue to influenza fowl plague virus hemagglutinin (HA) expressed from a second baculovirus. ${ }^{77}$ Although the overexpression of GlcNAc-TI resulted in a 4-fold increase in the amount of HA containing more complex N-glycan residues, only $40 \%$ of the total HA contained the GlcNAc addition (Table 1 ; line 3 ). ${ }^{77}$

Several important factors likely contributed to the observed heterogeneous glycosylation. It is possible that not all cells were infected with both baculoviruses during coinfection, resulting in target protein expression without the glycotransferase or vice versa. To address this limitation of coinfection, baculovirus vectors have been designed to express both the glycotransferases and the target protein using a single baculovirus. ${ }^{78,79}$ Infection of a single baculovirus ensures that the infected cells express all proteins of interest, while also reducing cell lysis as less baculovirus is used. This singleinfection strategy has been facilitated by the development of the MultiBac system, a baculovirus vector that contains two cloning sites (LoxP and Tn7) ${ }^{80,81}$ Using this system, the genes encoding the heavy and light chains of the 3D6 antibody against the HIV-1 Gag protein were transposed into the Tn7 site, while two glycotransferases (Caenorhabditis elegans $\mathrm{N}$-acetylglucosaminyltransferase II (GlcNAc-TII) and bovine $\beta$-1,4-galactosyltransferase I (GalT) were recombined into the LoxP site. When High Five cells were infected with this engineered MultiBac vector, 50\% of the 3D6 antibodies produced contained biantennary terminal galactose residues (Table 1; line 15). ${ }^{82}$ Although there was a $25 \%$ reduction in 3D6 antibody expression with the coexpression of the glycotransferases, the resulting 3D6 antibody with more humanized glycosylation showed enhanced binding to human $\mathrm{Fc} \gamma$ receptors, indicating improved effector functionality. ${ }^{82}$

In addition to expressing mammalian glycotransferases, engineering efforts have focused on eliminating insect-specific glycan structures such as $a-1,3$ core fucose that are allergenic. To achieve this goal, a GDP-6-deoxy-D-lyxo-4-hexulose reductase (RMD) native to bacteria has been used to inhibit fucosylation by consuming the GDP-I-fucose precursor. ${ }^{83,84}$ When expressed by a tandem gp64-polh promoter with both early and late activity, fucosylation of soluble influenza HA was significantly reduced and showed as much as a 10-fold decrease in reactivity to $\operatorname{IgE}$ when tested against the sera of patients with honeybee allergy. ${ }^{83}$ However, fucosylation was not completely eliminated. Another study used a baculovirus encoding RMD under the ie1 promoter and demonstrated an undetectable level of fucosylation on the target protein rituximab (CD20-IgG) ${ }^{84}$ Comparing these two studies, the choice of promoter may play a key role in the elimination of fucosylation. 


\section{EMERGING VIRUS-LESS GENOME EDITING AND GENE EXPRESSION}

While BEVS has played an instrumental role in catalyzing the field of insect cell-derived protein therapeutics, the issues associated with cell lysis as described in Section 2 are difficult to solve due to the lytic nature of BEVS. By implementing virus-less genetic modification strategies for heterologous gene expression, cell lysis can be dramatically reduced to simplify the purification process of protein therapeutics. To achieve virus-less expression of proteins with homogeneous humanized glycosylation in insect cells, the key is to develop an efficient genome editing tool with two important features: (1) high-level expression of mammalian glycotransferases as well as the target protein, and (2) efficient knockout of genes responsible for pathogenic glycan structures (e.g., $a-1,3$ core fucose) or preventing $\mathrm{N}$-glycan elongation (e.g., $\mathrm{N}$-acetylglucosaminidase).

Efforts based on random integration have achieved some success and enabled virus-less expression of up to nine heterologous genes in both S2 and Sf9 insect cells, producing target proteins with $40 \%$ of all glycan structures containing terminal sialic acid residues (Table 1; lines 5-13). However, screening for clones expressing glycotransferases or the target protein at high levels is difficult due to the low throughput and lengthy process of random integration. Furthermore, its random nature makes it inapplicable for knockout of a specific gene. Recent advances in genome editing have greater potential to address these challenges.

\subsection{Flipase-Enabled Screening of High-Expressing Loci and Targeted Integration in Situ.}

The location of an integrated gene within a chromosome has been shown to be a strong determinant of its transcriptional efficiency, leading to either no expression or variances of up to 1000-fold ${ }^{85-89}$ Flipase-based recombination, discovered in Saccharomyces cerevisiae in $1982,{ }^{90}$ has been used to screen high-expressing chromosomal loci to maximize the yield of protein therapeutics in $E$. coll ${ }^{91}$ and mammalian cells. ${ }^{92,93}$ This method has only been recently adopted in one of the insect cell lines, namely, Sf9, for the continuous expression of therapeutically relevant virus-like particles (VLPs). ${ }^{94,95}$ Flipase-based recombination integrates the target gene into the high-expressing locus through two rounds of integration: tagging followed by targeting. ${ }^{96,97}$ Flipase is an enzyme that recombines any two DNA sequences flanked by the 34-base pair flipase recognition sites. In the first tagging integration round, a reporter gene (e.g., GFP) flanked by the flipase recognition sites ${ }^{96,97}$ is randomly integrated, and high-expressing cells are isolated by fluorescence activated cell sorting (FACS) (Figure 3, weeks 1 and 2). ${ }^{96,97}$ The sorted cells thus contain high-expressing loci tagged with the flipase recognition sites. These cells are expanded to generate master cell lines (Figure 3, weeks 3-10) for further engineering of high-yield clones. In the second targeting integration round, cotransfection of (1) the gene of interest (GOI) flanked by the flipase recognition sites and (2) the flipase into the master cell lines allow for the targeted integration of the GOI into the high-expressing locus that has been tagged (Figure 3, weeks 11 and 12).

One round of tagging integration as described above using GFP as a reporter gene created a master cell line with a high-expressing locus in the Sf9 genome tagged with the flipase recognition sites. ${ }^{96,97}$ Using this master cell line in the second targeting integration round, rotavirus capsid VP2 ${ }^{94}$ VLPs were produced in Sf9 cells at a yield comparable to that using 
BEVS. More importantly, this stable Sf9 cell line showed significantly reduced cell lysis; cells continuously grew over more than a week to a density of up to $\sim 1.2 \times 10^{7}$ per mL.

In theory, additional rounds of tagging and targeting integration could introduce more copies of the GOI (e.g., genes encoding multiple glycotransferases or target glycoprotein) into the genome to further enhance their expression level. This process can be time consuming since each round takes 12 weeks due to the lengthy random integration and selection steps (Figure 3). However, once a master cell line with the tagged high-expressing loci is obtained, the timeline for future integrations is significantly reduced to 2 weeks, offering extraordinary flexibility to produce a variety of different protein therapeutics.

\subsection{CRISPR-Enabled Site-Specific Modification.}

While the flipase-based recombination achieves some degree of site-specific genome integration, it may be inefficient in exploring the chromatin landscape due to its reliance on random integration. Clustered regularly interspaced short palindromic repeats (CRISPR) represents a more efficient approach for site-specific genome editing. CRISPR has been used to perform not only gene insertions but also deletions and point mutations in many types of organisms (e.g., E. coli, yeast, plant, mammalian). ${ }^{98,99}$ Therefore, CRISPR possesses both features that are important for achieving virus-less expression of humanized proteins in insect cells. CRISPR uses an RNA-guided endonuclease to generate a double stranded break in the genome. The damaged genome induces cellular repair systems to fix the break resulting in either error-prone nonhomologous end joining (NHEJ) or homology-directed repair (HDR) if a homologous template is present. Whereas NHEJ is useful to knock out genes, HDR is required to efficiently integrate genes.

CRISPR has already been adopted in insect cells. Early studies have demonstrated that CRISPR can be used for gene knockout in the embryos and cell lines of Drosophila and Bombyx. ${ }^{100-104}$ The use of CRISPR for glycoengineering in insect cells was first demonstrated in the $\mathrm{S} 2$ cell line. Knockout of the $\mathrm{N}$-acetylglucosaminidase gene enabled a 4-fold increase in terminal GlcNAc residues on recombinant human erythropoietin (hEPO). 105 In Sf9 cells, this same gene knockout was enabled by the sequence identification of an Sf9-U6 promoter needed for the transcription of the guide RNA. ${ }^{106}$

The knockin of genes ( 27-1800 nucleotides) has also been shown in S2 and Bombyx cells using CRISPR. ${ }^{102-104}$ Typical knockin efficiencies in insect cell lines were reported in the range of $1 \%-6 \% .{ }^{102,103}$ To increase the knockin efficiency, one strategy is to inhibit the NHEJ pathway and promote HDR. RNAi-mediated knockdown of Ligase IV in S2 cells enhanced the efficiency of GFP ( 1700 nucleotides) knockin at the phosphoglycerate kinase (PGK) locus to $35 \% .{ }^{103}$ Gene knockin has not yet been accomplished in Sf9 or High Five cells due to the lack of the genome sequence. The recent publication of the Sf9 and High Five genomes ${ }^{107,108}$ opens many possibilities in the near future. For example, multiple copies of genes encoding mammalian glycotransferases can be knocked in to facilitate highlevel expression. ${ }^{109}$ Given the short timeline of genome editing using CRISPR ( 2 weeks as shown in Figure 3), glycoengineering of stable insect cell lines to produce humanized protein therapeutics is expected to be greatly accelerated. 


\section{CONCLUSIONS AND OUTLOOK}

Compared to BEVS, virus-less genetic engineering of insect cells has demonstrated several advantages for the development and manufacturing of protein therapeutics, most notably the significant reduction of cell lysis during protein expression. Nevertheless, both approaches face the challenge of glyco-engineering insect cells to produce protein therapeutics with humanized glycosylation, which is critical to ensure product efficacy and safety. The recent successful demonstration of CRISPR in Sf9, the publication of the Sf9 and High Five genomes, and the foundational CRISPR developments in Drosophila and Bombyx point to a new and exciting direction for virus-less engineering of insect cells. CRISPR has been innovatively adopted in a wide range of cell types and is expected to initiate a rapid expansion of engineering strategies to achieve high-level expression of multiple genes in insect cells. This is a timely development necessitated by the equally rapid growing protein therapeutics market. These most recent and anticipated future advances in engineering insect cells for high-yield production of humanized proteins are dissolving perceived disadvantages to bring about the coming age of insect cells for the manufacturing and development of protein therapeutics.

\section{ACKNOWLEDGMENTS}

This work was supported by the National Science Foundation (NSF) Grants 1511720 and 1645229 and CAREER Award 1653611 and the National Institute of Health (NIH) Grant OD020053. We thank members of the Wen research group, especially Mason Smith for valuable feedback and comments. This invited contribution is part of the Industrial \& Engineering Chemistry Research special issue for the 2018 Class of Influential Researchers.

\section{ABBREVIATIONS}

BEVS

CRISPR

Sf9

polh

p10

VLP

$\beta 4$ GalT

ST6Gal

ST3Gal

GlcNAc-TI

GlcNAc-TII
Baculovirus Expression Vector System

Clustered Regularly Interspaced Short Palindromic Repeats

Spodoptera frugiperda cell line

polyhedrin promoter

p10 promoter

Virus-Like Particle

$\beta-1,4$-galactosyltransferase

$a$-2,6-sialyltransferase

$a$-2,3-sialyltransferase

$\mathrm{N}$-acetylglucosaminyltransferase I

$\mathrm{N}$-acetylglucosaminyltransferase II 


\section{REFERENCES}

(1). Protein Therapeutics Market Analysis and Trends - Therapeutic Proteins, Application, Function Forecast to 2025 https://www.researchandmarkets.com/research/6mntwc/protein (accessed Jan. $15,2018)$.

(2). Lagasse HAD; Alexaki A; Simhadri VL; Katagiri NH; Jankowski W; Sauna ZE; Kimchi-Sarfaty C Recent Advances in (Therapeutic Protein) Drug Development [Version 1; Referees: 2 Approved]. F1000Research 2017, 6 (113), 113. [PubMed: 28232867]

(3). Leader B; Baca QJ; Golan DE Protein Therapeutics: A Summary and Pharmacological Classification. Nat. Rev. Drug Discovery 2008, 7 (1), 21. [PubMed: 18097458]

(4). Wen F; Rubin-Pitel SB; Zhao H Engineering of Therapeutic Proteins In Protein Engineering and Design;Park SJ, Cochran JR, Eds.; CRC Press, Taylor \& Francis Group: Boca Raton, FL, 2009; pp 153-177.

(5). Carter PJ Introduction to Current and Future Protein Therapeutics: A Protein Engineering Perspective. Exp. Cell Res 2011, 317 (9), 1261. [PubMed: 21371474]

(6). Hill BD; Zak A; Khera E; Wen F Engineering Virus-like Particles for Antigen and Drug Delivery. Curr. Protein Pept. Sci 2017, 19 (1), 112.

(7). Carton JM; Strohl WR Protein Therapeutics (Introduction to Biopharmaceuticals) In Introduction to Biological and Small Molecule Drug Research and Development; Elsevier, 2013; pp 127-159.

(8). Dumont J; Euwart D; Mei B; Estes S; Kshirsagar R Human Cell Lines for Biopharmaceutical Manufacturing: History, Status, and Future Perspectives. Crit. Rev. Biotechnol 2016, 36 (6), 1110. [PubMed: 26383226]

(9). Lalonde M-E; Durocher Y Therapeutic Glycoprotein Production in Mammalian Cells. J. Biotechnol 2017, 251, 128. [PubMed: 28465209]

(10). Jenkins N; Parekh RB; James DC Getting the Glycosylation Right: Implications for the Biotechnology Industry. Nat. Biotechnol 1996, 14 (8), 975. [PubMed: 9631034]

(11). Solá RJ; Griebenow K Glycosylation of Therapeutic Proteins. BioDrugs 2010, 24 (1), 9. [PubMed: 20055529]

(12). Costa AR; Rodrigues ME; Henriques M; Oliveira R; Azeredo J Glycosylation: Impact, Control and Improvement during Therapeutic Protein Production. Crit. Rev. Biotechnol 2014, 34 (4), 281. [PubMed: 23919242]

(13). Chen Q Virus-like Particle Vaccines for Norovirus Gastroenteritis In Molecular Vaccines: From Prophylaxis to Therapy, Vol. 1;Giese M, Ed.; Springer Verlag: Berlin, 2013; pp 162-163.

(14). Chen R Bacterial Expression Systems for Recombinant Protein Production: E. Coli and Beyond. Biotechnol. Adv 2012, 30 (5), 1102. [PubMed: 21968145]

(15). Celik E; Calik P Production of Recombinant Proteins by Yeast Cells. Biotechnol. Adv 2012, 30 (5), 1108. [PubMed: 21964262]

(16). Wen F; Sethi DK; Wucherpfennig KW; Zhao H Cell Surface Display of Functional Human MHC Class II Proteins: Yeast Display versus Insect Cell Display. Protein Eng., Des. Sel 2011, 24 (9), 701. [PubMed: 21752831]

(17). Lynn DE Novel Techniques to Establish New Insect Cell Lines. In Vitro Cell. Dev. Biol.: Anim 2001, 37 (6), 319. [PubMed: 11515961]

(18). Smagghe G; Goodman CL; Stanley D Insect Cell Culture and Applications to Research and Pest Management. In Vitro Cell. Dev. Biol.: Anim 2009, 45 (3-4), 93. [PubMed: 19247722]

(19). Ikonomou L; Schneider Y-J; Agathos SN Insect Cell Culture for Industrial Production of Recombinant Proteins. Appl. Microbiol. Biotechnol 2003, 62 (1), 1. [PubMed: 12733003]

(20). Kost TA; Condreay JP; Jarvis DL Baculovirus as Versatile Vectors for Protein Expression in Insect and Mammalian Cells. Nat. Biotechnol 2005, 23 (5), 567. [PubMed: 15877075]

(21). Airenne KJ; Hu Y-C; Kost TA; Smith RH; Kotin RM; Ono C; Matsuura Y; Wang S; YlaHerttuala S Baculovirus: An Insect-Derived Vector for Diverse Gene Transfer Applications. Mol. Ther 2013, 21 (4), 739. [PubMed: 23439502] 
(22). Smith GE; Summers MD; Fraser MJ Production of Human Beta Interferon in Insect Cells Infected with a Baculovirus Expression Vector. Mol. Cell. Biol 1983, 3 (12), 2156. [PubMed: 6318086]

(23). Smith GE; Summers MD Method for Producing a Recombinant Baculovirus Expression Vector. U.S. Patent US4745051A, 5 27, 1983.

(24). Luckow VA; Summers MD Trends in the Development of Baculovirus Expression Vectors. Nat. Biotechnol 1988, 6 (1), 47.

(25). () Jarvis DL; Fleming J-AGW; Kovacs GR; Summers MD; Guarino LA Use of Early Baculovirus Promoters for Continuous Expression and Efficient Processing of Foreign Gene Products in Stably Transformed Lepidopteran Cells. Nat. Biotechnol 1990, 8 (10), 950.

(26). Van Oers MM; Pijlman GP; Vlak JM Thirty Years of Baculovirus-insect Cell Protein Expression: From Dark Horse to Mainstream Technology. J. Gen. Virol 2015, 96, 6. [PubMed: 25246703]

(27). Ooi BG; Rankin C; Miller LK Downstream Sequences Augment Transcription from the Essential Initiation Site of a Baculovirus Polyhedrin Gene. J. Mol. Biol 1989, 210 (4), 721. [PubMed: 2693741]

(28). Morris TD; Miller LK Promoter Influence on Baculovirus-Mediated Gene Expression in Permissive and Nonpermissive Insect Cell Lines. J. Virol 1992, 66 (12), 7397. [PubMed: 1433522]

(29). Jarvis DL; Weinkauf C; Guarino LA Immediate-Early Baculovirus Vectors for Foreign Gene Expression in Transformed or Infected Insect Cells. Protein Expression Purif. 1996, 8 (2), 191.

(30). Jarvis DL Developing Baculovirus-Insect Cell Expression Systems for Humanized Recombinant Glycoprotein Production. Virology 2003, 310 (1), 1. [PubMed: 12788624]

(31). Cox MMJ Recombinant Protein Vaccines Produced in Insect Cells. Vaccine 2012, 30 (10), 1759. [PubMed: 22265860]

(32). Kollewe C; Vilcinskas A Production of Recombinant Proteins in Insect Cells. Am. J. Biochem. Biotechnol 2013, 9 (3), 255.

(33). Monie A; Hung C-F; Roden R; Wu T-C Cervarix: A Vaccine for the Prevention of HPV 16, 18Associated Cervical Cancer. Biologics 2008, 2 (1), 97.

(34). Burch PA; Breen JK; Buckner JC; Gastineau DA; Kaur JA; Laus RL; Padley DJ; Peshwa MV; Pitot HC; Richardson RL; Smits BJ; Sopapan P; Strang G; Valone FH; Vuk-Pavlovic S Priming Tissue-Specific Cellular Immunity in a Phase I Trial of Autologous Dendritic Cells for Prostate Cancer. Clin. Cancer Res 2000, 6 (6), 2175. [PubMed: 10873066]

(35). Cheever MA; Higano CS PROVENGE (Sipuleucel-T) in Prostate Cancer: The First FDAApproved Therapeutic Cancer Vaccine. Clin. Cancer Res 2011, 17 (11), 3520. [PubMed: 21471425]

(36). Cecchini S; Virag T; Kotin RM Reproducible High Yields of Recombinant Adeno-Associated Virus Produced Using Invertebrate Cells in 0.02- to 200-Liter Cultures. Hum. Gene Ther 2011, 22 (8), 1021. [PubMed: 21381980]

(37). Cox MMJ; Hollister JR FluBlok, a next Generation Influenza Vaccine Manufactured in Insect Cells. Biologicals 2009, 37 (3), 182. [PubMed: 19297194]

(38). Fernandes F; Teixeira AP; Carinhas N; Carrondo MJ; Alves PM Insect Cells as a Production Platform of Complex Viruslike Particles. Expert Rev. Vaccines 2013, 12 (2), 225. [PubMed: 23414412]

(39. () Mena JA; Kamen AA Insect Cell Technology Is a Versatile and Rebust Vaccine Manufacturing Platform. Expert Rev. Vaccines 2011, 10 (7), 1063. [PubMed: 21806400]

(40). Vicente T; Roldao A; Peixoto C; Carrondo MJT; Alves PM Large-Scale Production and Purification of VLP-Based Vaccines. J. Invertebr. Pathol 2011, 107, S42. [PubMed: 21784230]

(41). Harrison RL; Jarvis DL Protein N-Glycosylation in the Baculovirus-Insect Cell Expression System and Engineering of Insect Cells to Produce "Mammalianized" Recombinant Glycoproteins. Adv. Virus Res 2006, 68, 159. [PubMed: 16997012]

(42). Hollister J; Grabenhorst E; Nimtz M; Conradt H; Jarvis DL Engineering the Protein NGlycosylation Pathway in Insect Cells for Production of Biantennary, Complex N-Glycans. Biochemistry 2002, 41 (50), 15093. [PubMed: 12475259] 
(43). McIntosh AH; Grasela JJ; Popham HJR ACMNPV In Permissive, Semipermissive, and Nonpermissive Cell Lines From Arthropoda. Vitr. Cell. Dev. Biol. - Anim 2005, 41 (8), 298.

(44). Iwanaga M; Takaya K; Katsuma S; Ote M; Tanaka S; Kamita SG; Kang W; Shimada T; Kobayashi M Expression Profiling of Baculovirus Genes in Permissive and Nonpermissive Cell Lines. Biochem. Biophys. Res. Commun 2004, 323 (2), 599. [PubMed: 15369793]

(45). Luckow VA; Lee SC; Barry GF; Olins PO Efficient Generation of Infectious Recombinant Baculoviruses by Site-Specific Transposon-Mediated Insertion of Foreign Genes into a Baculovirus Genome Propagated in Escherichia Coli. J. Virol 1993, 67 (8), 4566. [PubMed: 8392598]

(46). Hewitt CJ; Isailovic B; Mukwena NT; Nienow NT Basic Biotechnology In Basic Biotechnology;Ratledge C, Kristiansen B, Eds.; Cambridge University Press, 2006; pp 530-533.

(47). Fath-Goodin A; Kroemer J; Mo S; Reeves K; Webb BA Insect Viruses : Biotechnological Applications In Insect Viruses: Biotechnological Applications; Bonning BC, Maramorosch K, Shatkin AJ, Eds.; Advances in Virus Research, Vol. 68; Elsevier Academic Press: London, 2006; pp 75-90.

(48). Jarvis DL; Fleming J-AGW; Kovacs GR; Summers MD; Guarino LA Use of Early Baculovirus Promoters for Continuous Expression and Efficient Processing of Foreign Gene Products in Stably Transformed Lepidopteran Cells. Nat. Biotechnol 1990, 8 (10), 950.

(49). Kaba SA; Salcedo AM; Wafula PO; Vlak JM; van Oers MM Development of a Chitinase and VCathepsin Negative Bacmid for Improved Integrity of Secreted Recombinant Proteins. J. Virol. Methods 2004, 122 (1), 113. [PubMed: 15488628]

(50). Steele KH; Stone BJ; Franklin KM; Fath-Goodin A; Zhang X; Jiang H; Webb BA; Geisler C Improving the Baculovirus Expression Vector System with Vankyrin-Enhanced Technology. Biotechnol. Prog 2017, 33 (6), 1496. [PubMed: 28649776]

(51). Gomez-Sebastian S; Lopez-Vidal J; Escribano JM Significant Productivity Improvement of the Baculovirus Expression Vector System by Engineering a Novel Expression Cassette. PLoS One 2014, 9 (5), e96562. [PubMed: 24824596]

(52). Thompson CM; Petiot E; Mullick A; Aucoin MG; Henry O; Kamen AA Critical Assessment of Influenza VLP Production in Sf9 and HEK293 Expression Systems. BMC Biotechnol. 2015, 15 (1), 31. [PubMed: 25981500]

(53). Marek M; Merten O-W; Galibert L; Vlak JM; van Oers MM Baculovirus VP80 Protein and the F-Actin Cytoskeleton Interact and Connect the Viral Replication Factory with the Nuclear Periphery. J. Virol 2011, 85 (11), 5350. [PubMed: 21450830]

(54). Marek M; van Oers MM; Devaraj FF; Vlak JM; Merten O-W Engineering of Baculovirus Vectors for the Manufacture of Virion-Free Biopharmaceuticals. Biotechnol. Bioeng 2011, 108 (5), 1056. [PubMed: 21449023]

(55). Blissard GW; Wenz JR Baculovirus Gp64 Envelope Glycoprotein Is Sufficient to Mediate PHDependent Membrane Fusion. J. Virol 1992, 66 (11), 6829. [PubMed: 1404622]

(56). Monsma SA; Oomens AG; Blissard GW The GP64 Envelope Fusion Protein Is an Essential Baculovirus Protein Required for Cell-to-Cell Transmission of Infection. J. Virol 1996, 70 (7), 4607. [PubMed: 8676487]

(57). Oomens AGP; Blissard GW Requirement for GP64 to Drive Efficient Budding of Autographa Californica Multicapsid Nucleopolyhedrovirus. Virology 1999, 254 (2), 297. [PubMed: 9986796]

(58). Chaves LCS; Ribeiro BM; Blissard GW Production of GP64-Free Virus-like Particles from Baculovirus-Infected Insect Cells. J. Gen. Virol 2018, 99 (2), 265. [PubMed: 29300162]

(59). Mangor JT; Monsma SA; Johnson MC; Blissard GW A GP64-Null Baculovirus Pseudotyped with Vesicular Stomatitis Virus G Protein. J. Virol 2001, 75 (6), 2544. [PubMed: 11222677]

(60). Altmann F; Staudacher E; Wilson IBH; Marz L Insect Cells as Hosts for the Expression of Recombinant Glycoproteins In Glycotechnology; Springer: Boston, MA, 1999; pp 29-43.

(61). Shi X; Jarvis DL Protein N-Glycosylation in the Baculovirus-Insect Cell System. Curr. Drug Targets 2007, 8 (10), 1116. [PubMed: 17979671]

(62). Kornfeld R; Kornfeld S Assembly of Asparagine-Linked Oligosaccharides. Annu. Rev. Biochem 1985, 54 (1), 631. [PubMed: 3896128] 
(63). An Y; Rininger JA; Jarvis DL; Jing X; Ye Z; Aumiller JJ; Eichelberger M; Cipollo JF Comparative Glycomics Analysis of Influenza Hemagglutinin (H5N1) Produced in Vaccine Relevant Cell Platforms. J. Proteome Res 2013, 12 (8), 3707. [PubMed: 23848607]

(64). Toth AM; Kuo C-W; Khoo K-H; Jarvis DL A New Insect Cell Glycoengineering Approach Provides Baculovirus-Inducible Glycogene Expression and Increases Human-Type Glycosylation Efficiency. J. Biotechnol 2014, 182-183, 19.

(65). Sareneva T; Cantell K; Pyhala L; Pirhonen J; Julkunen I Effect of Carbohydrates on the Pharmacokinetics of Human Interferon- $\gamma$. J. Interferon Res 1993, 13 (4), 267. [PubMed: 8228387]

(66). Grossmann M; Wong R; Teh NG; Tropea JE; East-Palmer J; Weintraub BD; Szkudlinski MW Expression of Biologically Active Human Thyrotropin (HTSH) in a Baculovirus System: Effect of Insect Cell Glycosylation on HTSH Activity in Vitro and in Vivo. Endocrinology 1997, 138 (1), 92. [PubMed: 8977390]

(67). Kogelberg H; Tolner B; Sharma SK; Lowdell MW; Qureshi U; Robson M; Hillyer T; Pedley RB; Vervecken W; Contreras R; Begent RHJ; Chester KA Clearance Mechanism of a Mannosylated Antibody-enzyme Fusion Protein Used in Experimental Cancer Therapy. Glycobiology 2007, 17 (1), 36. [PubMed: 17000699]

(68). Wright A; Sato Y; Okada T; Chang KH; Endo T; Morrison SL In Vivo Trafficking and Catabolism of IgG1 Antibodies with Fc Associated Carbohydrates of Differing Structure. Glycobiology 2000, 10 (12), 1347. [PubMed: 11159927]

(69). Opanasopit P; Shirashi K; Nishikawa M; Yamashita F; Takakura Y; Hashida M In Vivo Recognition of Mannosylated Proteins by Hepatic Mannose Receptors and Mannan-Binding Protein. Am. J. Physiol. Liver Physiol 2001, 280 (5), G879.

(70). Lee SJ; Evers S; Roeder D; Parlow AF; Risteli J; Risteli L; Lee YC; Feizi T; Langen H; Nussenzweig MC Mannose Receptor-Mediated Regulation of Serum Glycoprotein Homeostasis. Science (Washington, DC, U. S.) 2002, 295 (5561), 1898.

(71). Lin S-C; Jan J-T; Dionne B; Butler M; Huang M-H; Wu C-Y; Wong C-H; Wu S-C Different Immunity Elicited by Recombinant H5N1 Hemagglutinin Proteins Containing Pauci-Mannose, High-Mannose, or Complex Type N-Glycans. PLoS One 2013, 8 (6), e66719. [PubMed: 23799128]

(72). de Vries RP; Smit CH; de Bruin E; Rigter A; de Vries E; Cornelissen LAHM; Eggink D; Chung NPY; Moore JP; Sanders RW; Hokke CH; Koopmans M; Rottier PJM; de Haan CAM GlycanDependent Immunogenicity of Recombinant Soluble Trimeric Hemagglutinin. J. Virol 2012, 86 (21), 11735. [PubMed: 22915811]

(73). Banerjee K; Michael E; Eggink D; van Montfort T; Lasnik AB; Palmer KE; Sanders RW; Moore JP; Klasse PJ Occluding the Mannose Moieties on Human Immunodeficiency Virus Type 1 Gp120 with Griffithsin Improves the Antibody Responses to Both Proteins in Mice. AIDS Res. Hum. Retroviruses 2012, 28 (2), 206. [PubMed: 21793733]

(74). Shan M; Klasse PJ; Banerjee K; Dey AK; Iyer SPN; Dionisio R; Charles D; Campbell-Gardener L; Olson WC; Sanders RW; Moore JP HIV-1 Gp120 Mannoses Induce Immunosuppressive Responses from Dendritic Cells. PLoS Pathog. 2007, 3 (11), e169. [PubMed: 17983270]

(75). Tretter V; Altmann F; Kubelka V; Marz L; Becker WM Fucose a 1,3-Linked to the Core Region of Glycoprotein N-Glycans Creates an Important Epitope for IgE from Honeybee Venom Allergic Individuals. Int. Arch. Allergy Immunol 2004, 102 (3), 259.

(76). Seismann H; Blank S; Braren I; Greunke K; Cifuentes L; Grunwald T; Bredehorst R; Ollert M; Spillner E Dissecting Cross-Reactivity in Hymenoptera Venom Allergy by Circumvention of $a$ -1,3-Core Fucosylation. Mol. Immunol 2010, 47 (4), 799. [PubMed: 19896717]

(77). Wagner R; Liedtke S; Kretzschmar E; Geyer H; Geyer R; Klenk HD Elongation of the N-Glycans of Fowl Plague Virus Hemagglutinin Expressed in Spodoptera Frugiperda (Sf9) Cells by Coexpression of Human Beta 1,2-N-Acetylglucosaminyltransferase I. Glycobiology 1996, 6 (2), 165. [PubMed: 8727789]

(78). Jarvis DL; Howe D; Aumiller JJ Novel Baculovirus Expression Vectors That Provide Sialylation of Recombinant Glycoproteins in Lepidopteran Insect Cells. J. Virol 2001, 75 (13), 6223. [PubMed: 11390627] 
(79). Sokolenko S; George S; Wagner A; Tuladhar A; Andrich JMS; Aucoin MG Co-Expression vs. Co-Infection Using Baculovirus Expression Vectors in Insect Cell Culture: Benefits and Drawbacks. Biotechnol. Adv 2012, 30 (3), 766. [PubMed: 22297133]

(80). Berger I; Fitzgerald DJ; Richmond TJ Baculovirus Expression System for Heterologous Multiprotein Complexes. Nat. Biotechnol 2004, 22 (12), 1583. [PubMed: 15568020]

(81). Koehler C; Sauter PF; Wawryszyn M; Girona GE; Gupta K; Landry JJM; Fritz MH-Y; Radic K; Hoffmann J-E; Chen ZA; Zou J; Tan PS; Galik B; Junttila S; Stolt-Bergner P; Pruneri G; Gyenesei A; Schultz C; Biskup MB; Besir H; Benes V; Rappsilber J; Jechlinger M; Korbel JO; Berger I; Braese S; Lemke EA Genetic Code Expansion for Multiprotein Complex Engineering. Nat. Methods 2016, 13 (12), 997. [PubMed: 27749839]

(82). Palmberger D; Wilson IBH; Berger I; Grabherr R; Rendic D SweetBac: A New Approach for the Production of Mammalianised Glycoproteins in Insect Cells. PLoS One 2012, 7 (4), e34226. [PubMed: 22485160]

(83). Palmberger D; Ashjaei K; Strell S; Hoffmann-Sommergruber K; Grabherr R Minimizing Fucosylation in Insect Cell-Derived Glycoproteins Reduces Binding to IgE Antibodies from the Sera of Patients with Allergy. Biotechnol. J 2014, 9 (9), 1206. [PubMed: 24753388]

(84). Mabashi-Asazuma H; Kuo C-WC-W; Khoo K-HK-H; Jarvis DL A Novel Baculovirus Vector for the Production of Nonfucosylated Recombinant Glycoproteins in Insect Cells. Glycobiology 2014, 24 (3), 325. [PubMed: 24362443]

(85). Walters MC; Magis W; Fiering S; Eidemiller J; Scalzo D; Groudine M; Martin DI Transcriptional Enhancers Act in Cis to Suppress Position-Effect Variegation. Genes Dev. 1996, 10 (2), 185. [PubMed: 8566752]

(86). () Sabl JF; Henikoff S Copy Number and Orientation Determine the Susceptibility of a Gene to Silencing by Nearby Heterochromatin in Drosophila. Genetics 1996, 142 (2), 447. [PubMed: 8852844]

(87). () Day CD; Lee E; Kobayashi J; Holappa LD; Albert H; Ow DW Transgene Integration into the Same Chromosome Location Can Produce Alleles That Express at a Predictable Level, or Alleles That Are Differentially Silenced. Genes Dev. 2000, 14 (22), 2869. [PubMed: 11090134]

(88). () West AG; Fraser P Remote Control of Gene Transcription. Hum. Mol. Genet 2005, 14, R101. [PubMed: 15809261]

(89). Akhtar W; de Jong J; Pindyurin AV; Pagie L; Meuleman W; de Ridder J; Berns A; Wessels LFA; van Lohuizen M; van Steensel B Chromatin Position Effects Assayed by Thousands of Reporters Integrated in Parallel. Cell 2013, 154 (4), 914. [PubMed: 23953119]

(90). Broach JR; Guarascio VR; Jayaram M Recombination within the Yeast Plasmid $2 \mu$ Circle Is SiteSpecific. Cell 1982, 29 (1), 227. [PubMed: 6286142]

(91). Gu P; Yang F; Su T; Wang Q; Liang Q; Qi Q A Rapid and Reliable Strategy for Chromosomal Integration of Gene(s) with Multiple Copies. Sci. Rep 2015, 5 (1), 9684. [PubMed: 25851494]

(92). Nehlsen K; Schucht R; da Gama-Norton L; Kromer W; Baer A; Cayli A; Hauser H; Wirth D Recombinant Protein Expression by Targeting Pre-Selected Chromosomal Loci. BMC Biotechnol. 2009, 9 (1), 100. [PubMed: 20003421]

(93). Mayrhofer P; Kratzer B; Sommeregger W; Steinfellner W; Reinhart D; Mader A; Turan S; Qiao J; Bode J; Kunert R Accurate Comparison of Antibody Expression Levels by Reproducible Transgene Targeting in Engineered Recombination-Competent CHO Cells. Appl. Microbiol. Biotechnol 2014, 98 (23), 9723. [PubMed: 25158835]

(94). Fernandes F; Dias MM; Vidigal J; Sousa MFQ; Patrone M; Teixeira AP; Alves PM Production of Rotavirus Core-like Particles in Sf9 Cells Using Recombinase-Mediated Cassette Exchange. J. Biotechnol 2014, 171, 34. [PubMed: 24333128]

(95). Vidigal J; Fernandes B; Dias MM; Patrone M; Roldao A; Carrondo MJT; Alves PM; Teixeira AP RMCE-Based Insect Cell Platform to Produce Membrane Proteins Captured on HIV-1 Gag Virus-like Particles. Appl. Microbiol. Biotechnol 2018, 102 (2), 655. [PubMed: 29143881]

(96). Fernandes F; Vidigal J; Dias MM; Prather KLJ; Coroadinha AS; Teixeira AP; Alves PM FlipaseMediated Cassette Exchange in Sf 9 Insect Cells for Stable Gene Expression. Biotechnol. Bioeng 2012, 109 (11), 2836. [PubMed: 22565981] 
(97). Vidigal J; Fernandes F; Coroadinha AS; Teixeira AP; Alves PM Insect Cell Line Development Using Flp-Mediated Cassette Exchange Technology; Humana Press, Totowa, NJ, 2014; pp 1527.

(98). Doudna JA; Charpentier E The New Frontier of Genome Engineering with CRISPR-Cas9. Science (Washington, DC, U. S.) 2014, 346 (6213), 1258096.

(99). Sander JD; Joung JK CRISPR-Cas Systems for Editing, Regulating and Targeting Genomes. Nat. Biotechnol 2014, 32 (4), 347. [PubMed: 24584096]

(100). Gratz SJ; Cummings AM; Nguyen JN; Hamm DC; Donohue LK; Harrison MM; Wildonger J; O'Connor-Giles KM Genome Engineering of Drosophila with the CRISPR RNA-Guided Cas9 Nuclease. Genetics 2013, 194 (4), 1029. [PubMed: 23709638]

(101). Baena-Lopez LA; Alexandre C; Mitchell A; Pasakarnis L; Vincent J-P Accelerated Homologous Recombination and Subsequent Genome Modification in Drosophila. Development 2013, 140 (23), 4818. [PubMed: 24154526]

(102). Bassett AR; Tibbit C; Ponting CP; Liu J-L Mutagenesis and Homologous Recombination in Drosophila Cell Lines Using CRISPR/Cas9. Biol. Open 2014, 3 (1), 42. [PubMed: 24326186]

(103). Böttcher R; Hollmann M; Merk K; Nitschko V; Obermaier C; Philippou-Massier J; Wieland I; Gaul U; Forstemann K Efficient Chromosomal Gene Modification with CRISPR/Cas9 and PCRBased Homologous Recombination Donors in Cultured Drosophila Cells. Nucleic Acids Res. 2014, 42 (11), e89. [PubMed: 24748663]

(104). Zhu L; Mon H; Xu J; Lee JM; Kusakabe T CRISPR/ Cas9-Mediated Knockout of Factors in Non-Homologous End Joining Pathway Enhances Gene Targeting in Silkworm Cells. Sci. Rep 2016, 5, 18103.

(105). Mabashi-Asazuma H; Kuo C-W; Khoo K-H; Jarvis DL Modifying an Insect Cell N -Glycan Processing Pathway Using CRISPR-Cas Technology. ACS Chem. Biol 2015, 10 (10), 2199. [PubMed: 26241388]

(106). Mabashi-Asazuma H; Jarvis DL CRISPR-Cas9 Vectors for Genome Editing and Host Engineering in the Baculovirus-insect Cell System. Proc. Natl. Acad. Sci. U. S. A 2017, 114 (34), 9068. [PubMed: 28784806]

(107). Nandakumar S; Ma H; Khan AS Whole-Genome Sequence of the Spodoptera Frugiperda Sf9 Insect Cell Line. Genome Announc 2017, 5 (34), e00829-17. [PubMed: 28839023]

(108). Fu Y; Yang Y; Zhang H; Farley G; Wang J; Quarles KA; Weng Z; Zamore PD The Genome of the Hi5 Germ Cell Line from Trichoplusia Ni, an Agricultural Pest and Novel Model for Small RNA Biology. eLife 2018, 7, e31628. [PubMed: 29376823]

(109). Wirth M; Bode J; Zettlmeissl G; Hauser H Isolation of Overproducing Recombinant Mammalian Cell Lines by a Fast and Simple Selection Procedure. Gene 1988, 73 (2), 419. [PubMed: 3072266]

(110). Zitzmann J; Sprick G; Weidner T; Schreiber C; Czermak P Process Optimization for Recombinant Protein Expression in Insect Cells. In New Insights into Cell Culture Technology; InTech, 2017.

(111). Walsh G Biopharmaceutical Benchmarks 2014. Nat. Biotechnol 2014, 32 (10), 992. [PubMed: 25299917]

(112). Fore J; Wiechers IR; Cook-Deegan R The Effects of Business Practices, Licensing, and Intellectual Property on Development and Dissemination of the Polymerase Chain Reaction: Case Study. J. Biomed. Discovery Collab 2006, 1, 7.

(113). Crisci E; Barcena J; Montoya M Virus-like Particle-Based Vaccines for Animal Viral Infections. Inmunologia 2013, 32 (3), 102.

(114). Uetrecht C; Rose RJ; van Duijn E; Lorenzen K; Heck AJR Ion Mobility Mass Spectrometry of Proteins and Protein Assemblies. Chem. Soc. Rev 2010, 39 (5), 1633. [PubMed: 20419213]

(115). Jarvis DL; Finn EE Modifying the Insect Cell N-Glycosylation Pathway with Immediate Early Baculovirus Expression Vectors. Nat. Biotechnol 1996, 14 (10), 1288. [PubMed: 9631095]

(116). Hollister JR; Shaper JH; Jarvis DL Stable Expression of Mammalian Beta 1,4Galactosyltransferase Extends the N-Glycosylation Pathway in Insect Cells. Glycobiology 1998, 8 (5), 473. [PubMed: 9597545] 
(117). () Hollister JR; Jarvis DL Engineering Lepidopteran Insect Cells for Sialoglycoprotein Production by Genetic Transformation with Mammalian Beta 1,4-Galactosyltransferase and Alpha 2,6-Sialyltransferase Genes. Glycobiology 2001, 11 (1), 1. [PubMed: 11181556]

(118). () Aumiller JJ; Hollister JR; Jarvis DL A Transgenic Insect Cell Line Engineered to Produce CMP-Sialic Acid and Sialylated Glycoproteins. Glycobiology 2003, 13 (6), 497. [PubMed: 12626399]

(119). () Mabashi-Asazuma H; Shi X; Geisler C; Kuo C-W; Khoo K-H; Jarvis DL Impact of a Human CMP-Sialic Acid Transporter on Recombinant Glycoprotein Sialylation in Glycoengineered Insect Cells. Glycobiology 2013, 23 (2), 199. [PubMed: 23065352]

(120). () Geisler C; Jarvis DL Innovative Use of a Bacterial Enzyme Involved in Sialic Acid Degradation to Initiate Sialic Acid Biosynthesis in Glycoengineered Insect Cells. Metab. Eng 2012, 14 (6), 642. [PubMed: 23022569]

(121). Chang KH; Yang JM; Chun HOK; Chung IS Enhanced Activity of Recombinant $\beta$-Secretase from Drosophila Melanogaster S2 Cells Transformed with CDNAs Encoding Human $\beta 1,4-$ Galactosyltransferase and Gal $\beta 1$,4-GlcNAc $a 2,6$-Sialyltransferase. J. Biotechnol 2005, 116 (4), 359. [PubMed: 15748762]

(122). Chang KH; Lee JM; Hwang-Bo J; Yoo KH; Sohn BH; Yang JM; Chung IS Expression of Recombinant Cyclooxygenase 1 in Drosophila Melanogaster S2 Cells Transformed with Human

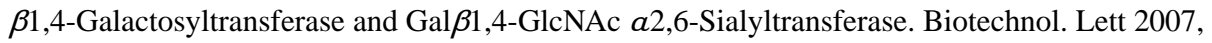
29 (12), 1803. [PubMed: 17665137] 


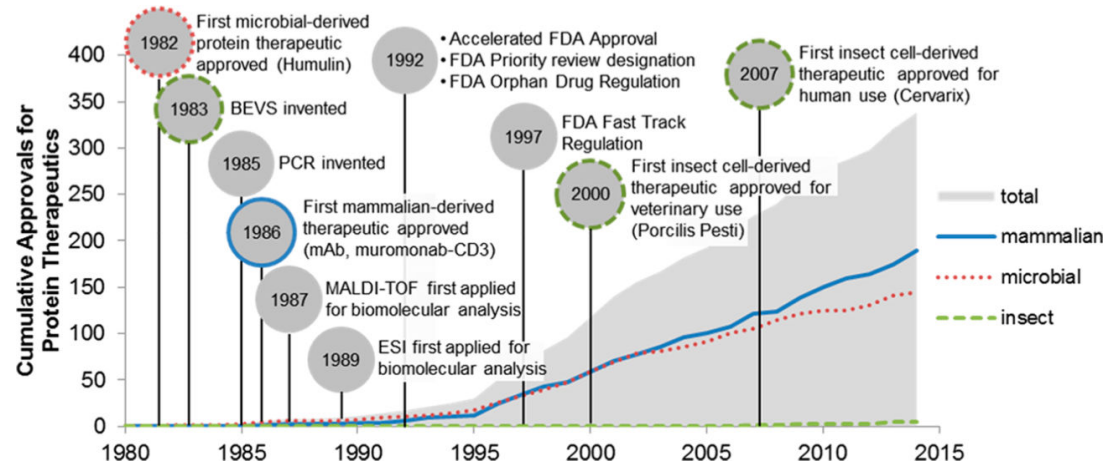

Figure 1.

Timeline of approvals made by the FDA and EMA for recombinant protein therapeutics for human use overlaid with significant technological advances and regulation events. ${ }^{2,110-114}$ 


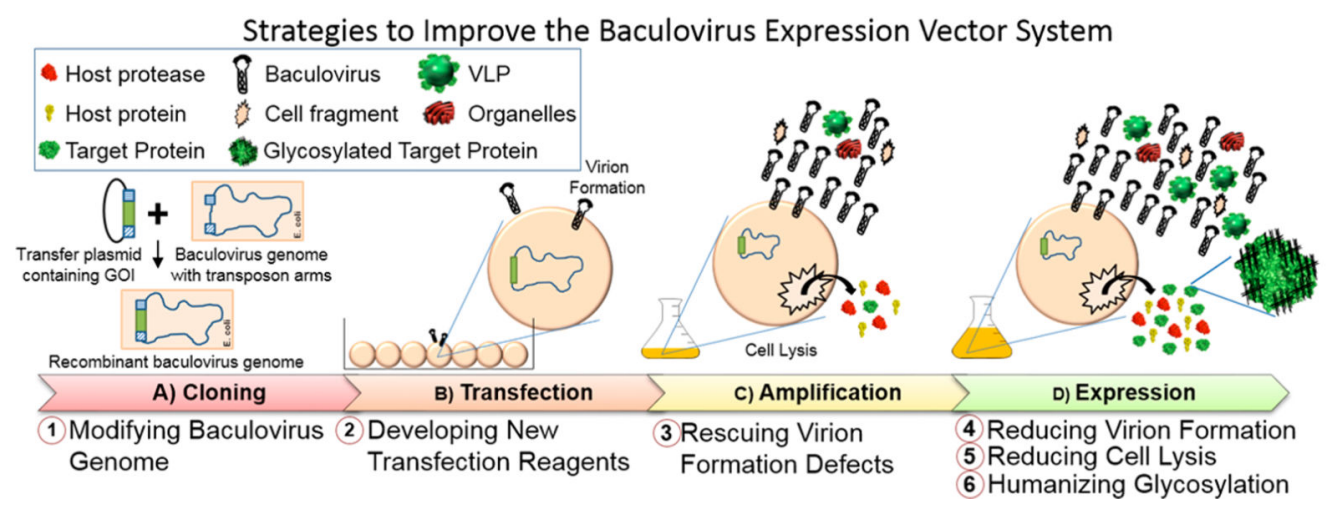

Figure 2.

Overview of the BEVS and strategies to address issues associated with product contamination and glycosylation. BEVS includes four major steps: (A) Cloning the gene of interest (GOI) into a transfer plasmid and transposing into the baculovirus genome in a specialized E. coli strain (DH10Bac). (B) Transfection of the purified recombinant baculovirus genome in insect cells to form recombinant baculovirus progeny (Note: direct homologous recombination in insect cells could also be used but is not shown for simplicity). (C) Amplification to generate high-titer viral stocks. (D) Expression of the target protein. The six strategies listed have been applied at one of the four steps. 


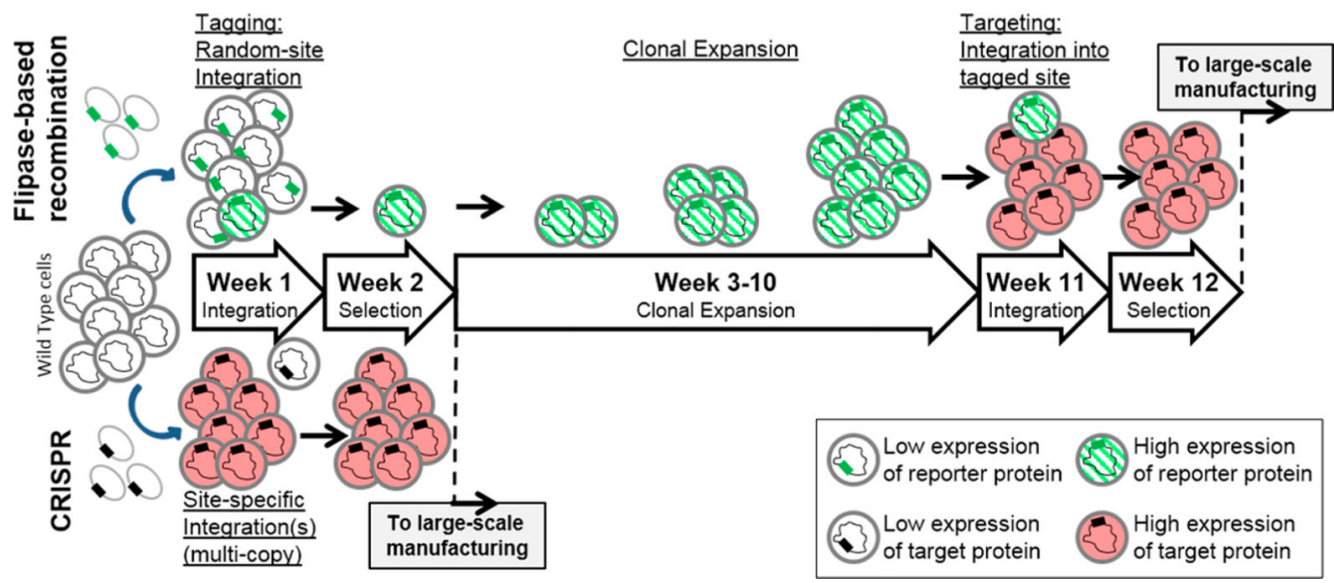

Figure 3.

Comparison of the flipase-based recombination method and CRISPR for creating a stable cell line. Flipase-based recombination first requires the "tagging" integration of a reporter gene into a random location of the genome. High-expressing clones are isolated and expanded as master cell lines. A "targeting" integration exchanges the reporter with the target protein cassette(s) through the use of flipase. CRISPR in theory requires one round of site-specific integration of the target protein; thus, it could accelerate the creation of stable cell lines. 


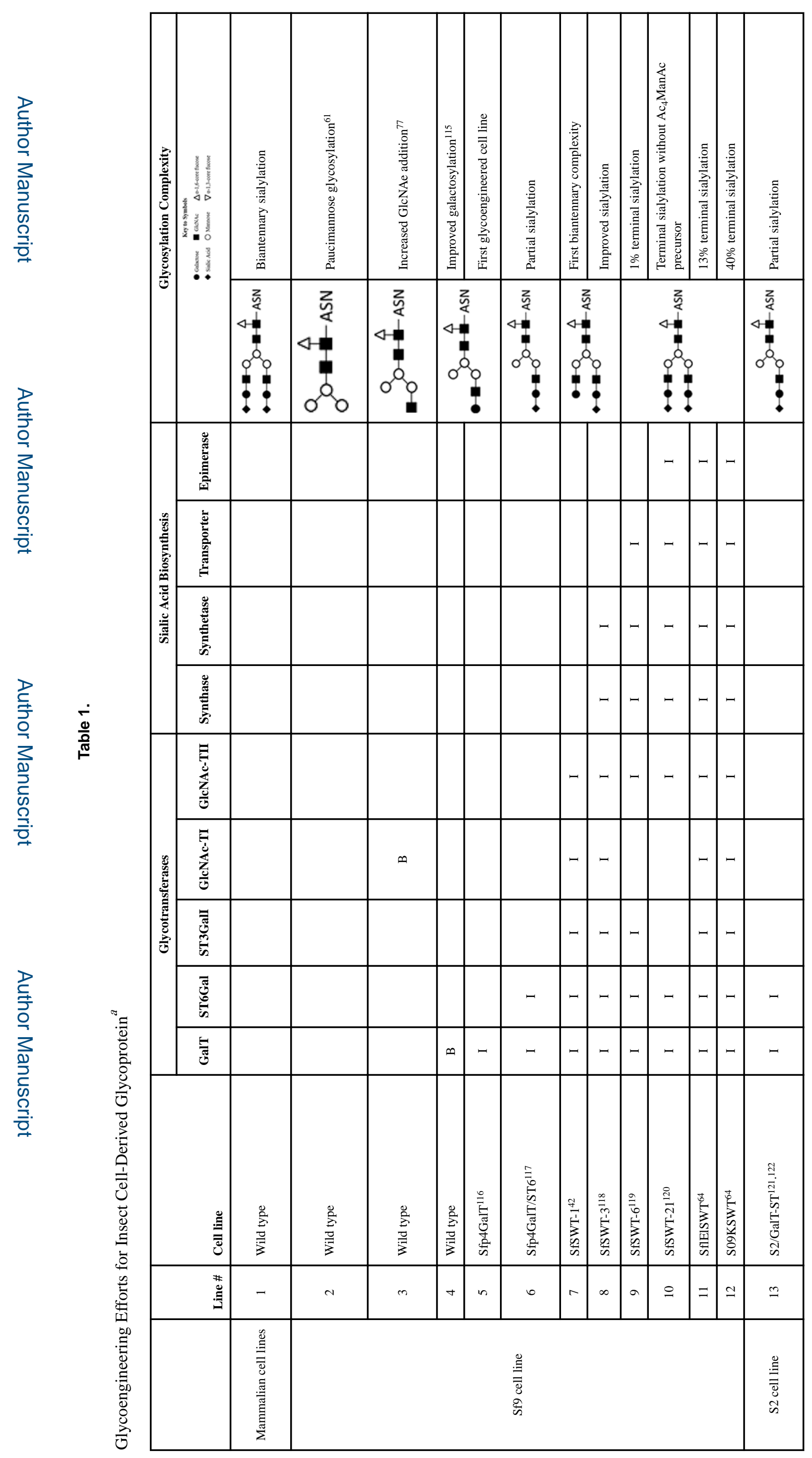




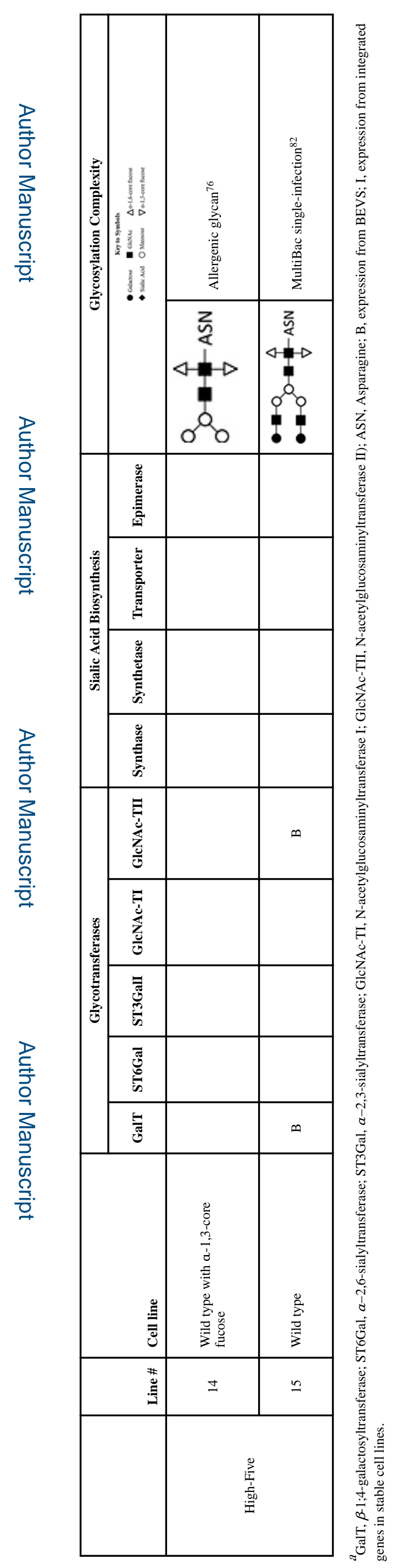

